\title{
Biochemical Composition of Muscle from Tanaka's Eelpout Lycodes tanakae, Magistrate Armhook Squid Berryteuthis magister, and Ocean Sunfish Mola mola, Caught in the East Sea, Korea
}

\author{
Doo Seog Lee, Hyeon Ah Cho, Na Young Yoon*, Yeon Kye Kim, Chi Won Lim and Kil Bo Shim \\ Food Safety Research Division, National Fisheries Research and Development Institute, Busan 619-705, Korea
}

\begin{abstract}
The biochemical composition of muscle from three deep-sea animals, Tanaka's eelpout Lycodes tanakae magistrate armhook squid Berryteuthis magister, and ocean sunfish Mola mola caught in the East sea in South Korea was determined. The moisture (81.4$93.8 \mathrm{~g} / 100 \mathrm{~g})$, crude protein (5.0-15.6 g/100 g), crude lipid (0.1-1.5 g/100 g), and ash (1.0-1.1 g/100 g) contents of the two fishes were analyzed. The proximate composition of magistrate armhook squid was: moisture $84.0 \mathrm{~g} / 100 \mathrm{~g}$, crude protein $12.4 \mathrm{~g} / 100 \mathrm{~g}$, crude lipid $0.7 \mathrm{~g} / 100 \mathrm{~g}$, and ash $1.5 \mathrm{~g} / 100 \mathrm{~g}$. There was little difference in the proximate compositions of the three animals. The total amino acid contents of Tanaka's eelpout, magistrate armhook squid, and ocean sunfish were 14.64, 10.75, 3.10-9.95 g/100 g, respectively. High levels of glutamic acid, aspartic acid, lysine, leucine, and arginine were found, while low levels of histidine, glycine, and cysteine were detected in the animals. A survey of the free amino acid contents of the animals revealed large amounts of alanine and glycine. Significant differences were found in the fatty acid composition among the three species. Specially, different saturated fatty acids (17.14-40.49\%) such as C16:0, and C18:0, monounsaturated fatty acids (19.19-46.88\%) such as C16:1, and C18:1, and polyunsaturated fatty acids (35.41-57.08\%) such as EPA, and DHA was identified. Our results suggest that each of these deep sea animals possesses nutritional value and should be considered as a foodstuff.
\end{abstract}

Key words: Lycodes tanakae, Berryteuthis magister, Mola mola, Biochemical composition, Amino acid, Proximate composition, Fatty acid

\section{Introduction}

In general, the deep sea is referred to as the watershed below $200 \mathrm{~m}$ at the end point of the continental shelf. The average depth of East Sea in Korea is about 1,700 m (Sohn et al., 2010). Deep sea water (beginning at a depth of $200 \mathrm{~m}$ ) has stable environmental characteristics, including a low temperature, high salinity, and an absence of penetration by natural light. The species diversity and number of inhabitants in the East Sea have been shown to be very low (Barnes and Mann, 1991; Park et al., 2007).
Several recent studies have raised awareness of the need to develop the marine resources that inhabit the deep sea. Coastal marine resources have become depleted as the number of fish catches has increased worldwide, and overfishing, promoted by technological developments in fishing boats and gear, is threatening future supplies.

Species known to inhabite the eastern deep sea in Korea include the snow crab Chionoecetes opilio, red snow crab Chionoecetes japonicus, Tanaka's eelpout Lycodes tanakae, kata-
Open Access http://dx.doi.org/10.5657/FAS.2012.0099

This is an Open Access article distributed under the terms of the Creative Commons Attribution Non-Commercial License (http://creativecommons. org/licenses/by-nc/3.0/) which permits unrestricted non-commercial use, distribution, and reproduction in any medium, provided the original work is properly cited. pISSN: 2234-1749 eISSN: 2234-1757
Received 6 April 2012; Revised 3 May 2012

Accepted 9 May 2012

*Corresponding Author

E-mail: dbssud@nfrdi.go.kr 

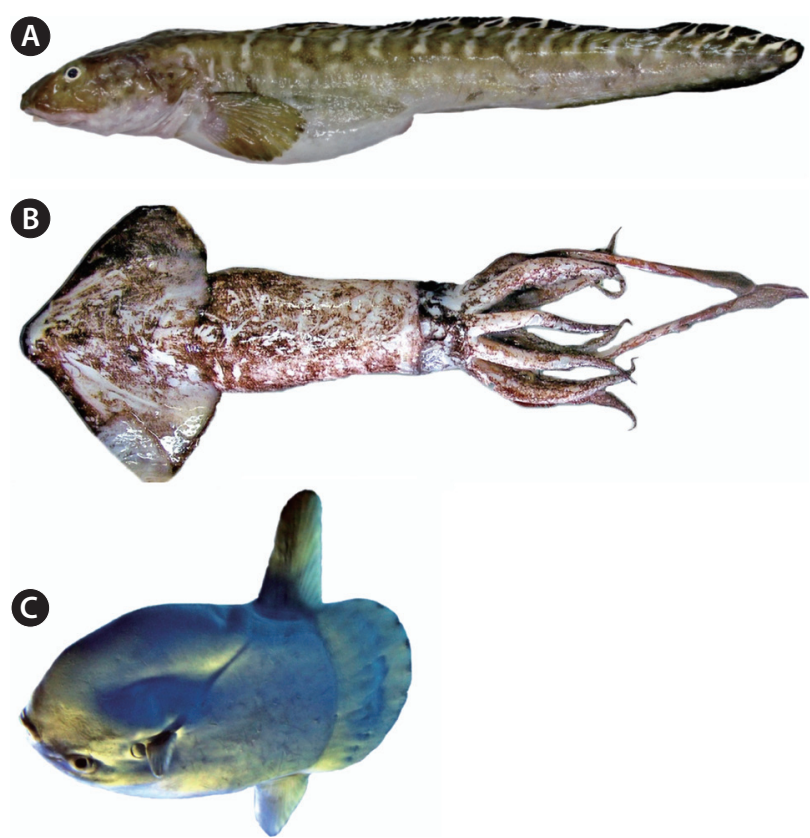

Fig. 1. The samples caught in the East Sea, Korea. (A) Tanaka's eelpout Lycodes tanakae, (B) Magistrate armhook squid Berryteuthis magister, (C) ocean sunfish Mola mola.

yama Petroschmidtia toyamensis, spinyhead sculpin Dasycottus setiger, black eellpout Lycodes nakamurae, ocean sunfish Mola mola, and magistrate armhook squid Berryteuthis magister.

The fishery characteristics, population variation, ecological characteristics, and geographical distribution of the aforementioned species have been studies (Kim et al., 2007).

However, around $50 \%$ of deep sea animals abandoned on fishing vessels because of a lack of consumer demand, likely because of their appearance and unfamiliar name. Thus, it is necessary to develop effective processing technologies and to ascertain the biochemical composition of the animals that inhabit the deep sea in order to expand the utilization of these resources as food (Park et al., 2007).

In this study, we examined the biochemical composition of muscle from Tanaka's eelpout $L$. tanakae, magistrate armhook squid B. magister, and ocean sunfish M. mola to enhance the availability of these species.

\section{Materials and Methods}

\section{Materials}

Tanaka's eelpout $L$. tanakae, magistrate armhook squid $B$. magister, and ocean sunfish M. mola were caught using a dip net in the East sea of Korea between June and July of 2011 (Fig. 1). After being caught, the animals were transferred to the laboratory on ice. Muscle from the fishes were sampled af- ter removal of the skin and innards; all parts of the squid were used, except for the intestines. The mean weights and length of the samples are shown in Table 1.

\section{Analytic methods}

\section{Proximate composition analysis}

The moisture content of the fishes was determined by drying the meat in an oven at $105^{\circ} \mathrm{C}$ until a constant weight was obtained (Association of Official Analytical Chemists, 1990). The crude protein content was calculated by converting the nitrogen content, determined by Kjeldahl's method $(6.25 \times$ N) (Association of Official Analytical Chemists, 1990). The crude lipid content was determined described by the Association of Official Analytical Chemists (1990) using the Soxhlet system. The ash content was determined by dry ashing in a furnace oven at $525^{\circ} \mathrm{C}$ for $24 \mathrm{~h}$. The carbohydrate content was determined as 100 minus the moisture, crude protein, crude lipid, and ash contents.

\section{Total amino acids}

The total amino acid composition was determined using an amino acid analyzer (S43000; Sykam, Eresing, Germany). All samples were hydrolyzed in $6 \mathrm{~N} \mathrm{HCl}$ in vacuum-sealed tubes at $110^{\circ} \mathrm{C}$ for $24 \mathrm{~h}$.

\section{Free amino acids}

Fifteen grams each of animals was placed in a Corning tube (Corning, NY, USA) containing $30 \mathrm{~mL}$ of extraction solvent $(100 \%$ ethanol) and blended for $1 \mathrm{~h}$. The extract was then transferred to a $100 \mathrm{~mL}$ volumetric flask and the tube was rinsed once with $30 \mathrm{~mL}$ of $70 \%$ ethanol then blended for 2 min using a sonicator (D78224; Singen, Elma, Germany). The filtrate was enriched using a rotary evaporator (N-1000; Eyela, Tokyo, Japan) and combined with $25 \mathrm{~mL}$ of the lithium citrate loading buffer $(\mathrm{pH}$ 2.2). The sample was passed through an Advantec cellulose acetate $0.20 \mu \mathrm{m}$ filter membrane and the free amino acid composition was determined using an amino acid analyzer (S43000; Sykam).

\section{Lipids extraction}

Total lipids were extracted according to the method of Folch et al. (1957), using chloroform/methanol (2:1). Aliquots

Table 1. The profiles of samples caught in the East Sea, Korea

\begin{tabular}{lccc}
\hline \multicolumn{1}{c}{ Species } & $\begin{array}{c}\text { Body } \\
\text { length }(\mathbf{c m})\end{array}$ & $\begin{array}{c}\text { Body } \\
\text { weight }(\mathbf{g})\end{array}$ & $\begin{array}{c}\text { Collection } \\
\text { date }\end{array}$ \\
\hline $\begin{array}{c}\text { Tanaka's eelpout } \\
\text { (Lycodes tanakae) }\end{array}$ & 50 & 579.8 & Jun 2011 \\
$\begin{array}{c}\text { Magistrate armhook squid } \\
\text { (Berryteuthis magister) }\end{array}$ & 60 & 395.6 & Jun 2011 \\
$\begin{array}{c}\text { Ocean sunfish } \\
\text { (Mola mola) }\end{array}$ & 150 & $120 \mathrm{~kg}$ & Jul 2011 \\
\hline
\end{tabular}


of the chloroform layer extract were evaporated to dryness under nitrogen and lipids were quantified gravimetrically.

\section{Fatty acid analysis}

Fatty acid methyl esters (FAMEs) were obtained as described by the American Oil Chemists' Society (1997). A fraction of the lipid extract was saponified with $0.5 \mathrm{~N} \mathrm{NaOH}$ in methanol followed by methylation in $14 \%$ boron trifluoride in methanol. The resulting methyl esters were analyzed using GC-17A gas chromatograph (Shimazu, Tokyo, Japan) equipped with a flame ionization detector, a split ratio (1:50) injector, and an Omegawax-320 capillary column (film thickness: $30 \mathrm{~m} \times 0.32 \mathrm{~mm}$; i.d $\times 0.25 \mu \mathrm{m})$. The temperatures of the injector and detector were 250 and $260^{\circ} \mathrm{C}$, respectively. Helium was used as the carrier gas (flow rate, $1.03 \mathrm{~mL} / \mathrm{min}$ ). Peaks were identified by comparison of their retention times with a 37 component FAMEs mixed standard (Supelco SA, Gland, Switzerland).

\section{Statistical analyses}

The data were analyzed using analysis of variance through the general linear model procedure (SAS Institute, Cary, NC, USA). Duncan's multiple-range test was applied to determine the significance of differences between means $(P<0.05)$.

\section{Results and Discussion}

\section{Proximate composition}

The proximate compositions of Tanaka's eelpout, magistrate armhook squid and ocean sunfish are shown in Table 2.

The moisture contents were $81.4 \pm 0.39,84.0 \pm 0.08,87.2 \pm$ 0.15 and $93.8 \pm 0.19 \mathrm{~g} / 100 \mathrm{~g}$ for Tanaka's eelpout, magistrate armhook squid, ocean sunfish's endosarc and sunfish's ectosarc, respectively. The crude lipid contents were $1.5 \pm 0.02$, $0.7 \pm 0.03,0.5 \pm 0.02$ and $0.1 \pm 0.01 \mathrm{~g} / 100 \mathrm{~g}$. The crude protein contents were $15.6 \pm 0.17,12.4 \pm 0.16,11.0 \pm 0.05$ and 5.0 $\pm 0.16 \mathrm{~g} / 100 \mathrm{~g}$. The ash contents were $1.1 \pm 0.00,1.5 \pm 0.01$, $1.0 \pm 0.11$ and $1.1 \pm 0.01 \mathrm{~g} / 100 \mathrm{~g}$. The carbohydrate contents were $0.3,1.4,0.2$ and $0.1 \mathrm{~g} / 100 \mathrm{~g}$. Finally, the energy contents of the animals were $77.1,61.5,49.3$ and $21.3 \mathrm{kcal}$, respectively; the highest content was in Tanaka's eelpout whilelowest was in sunfish's ectosarc.

These results show a clear inverse relationship between the lipid and moisture contents, with high lipid values being matched by a low moisture content and vice versa (Hernandez et al., 2003). The lipid stored in muscle is largely neutral lipids in the form of oil droplets (Shindo et al., 1986). These oil droplets were replaced by interstitial water; thus, the moisture content in the muscle was reduced while the crude protein content remained unchanged. An inverse relationship between these values has been shown (Ackman, 1989; Mok et al., 2007).

The reported average moisture content of 51 species of Korean coastal water fishes, including Japanese anchovy Engraulis joponicus, dotted gizzard shad Konosirus punctatus, Pacific cod Gadus macrocephalus, flathead grey mullet Mugil cephalus, darkbanded rockfish Sebastes inermis, Okhotsk atka mackeral Pleurogrammus azonus, gilthead seabream Sparus aurata and eyespotted puffer Takifugu chinensis, is $75.3 \pm 5.0$ $\mathrm{g} / 100 \mathrm{~g}$ (Mok et al., 2007). In comparison, the average crude protein content, crude lipid content, ash content and carbohydrate content of these fishes were $19.1 \pm 2.7,3.8 \pm 4.1,1.4 \pm$ 0.3 , and $0.4 \pm 0.3 \mathrm{~g} / 100 \mathrm{~g}$, respectively .

The levels of moisture (88.2-92.5\%), crude protein (7.0$9.9 \%)$, crude lipid $(0-0.1 \%)$, ash $(0.9-1.1 \%)$, and carbohydrate $(0-1.2 \%)$ in cubed snailfish Liparis tessellatus were analyzed previously, as were the moisture (79.9-84.0\%), crude protein (14.7-21.6\%), crude lipid (0-0.3\%), ash (1.0-1.7\%), and carbohydrate (0-2.1\%) contents in shaggy sea raven Hemitripterus villosus. The above numbers indicate high lipid values and low moisture contents in both of these demersal fish species (Lee and Surh, 2011).

With regard to demersal fish, most settlement fish, which exhibit low mobility owing to the face that they do not need to expend much energy were shown to have low lipid contents (Jeong et al., 1998a).

Deep sea fishes live longer than organisms on the continental shelf, and have a low growth rate (Park and Bae, 2011). The average moisture content in Tanaka's eelpout and sunfish was $>80 \mathrm{~g} / 100 \mathrm{~g}$ which is higher than that in coastal water

Table 2. Proximate composition ( $\mathrm{g} / 100 \mathrm{~g}$ ) of muscle from Tanaka's eelpout, magistrate armhook squid, and ocean sunfish

\begin{tabular}{ccccccc}
\hline Species & Moisture & Crude lipid & Crude protein & Ash & CHO \\
\hline $\begin{array}{c}\text { Tanaka's eelpout } \\
\text { (Lycodes tanakae) }\end{array}$ & $81.4 \pm 0.39$ & $1.5 \pm 0.02$ & $15.6 \pm 0.17$ & $1.1 \pm 0.00$ & 0.3 \\
$\begin{array}{c}\text { Magistrate armhook squid } \\
\text { (Berryteuthis magister) }\end{array}$ & $84.0 \pm 0.08$ & $0.7 \pm 0.03$ & $12.4 \pm 0.16$ & $1.5 \pm 0.01$ & 1.4 \\
$\begin{array}{c}\text { Ocean sunfish } \quad \text { endosarc } \\
\text { (Mola mola) }\end{array}$ & $87.2 \pm 0.15$ & $0.5 \pm 0.02$ & $11.0 \pm 0.05$ & $1.0 \pm 0.11$ & 0.2 \\
\hline
\end{tabular}

Carbohydrate $(\mathrm{CHO})=100-$ (Moisture + Crude protein + Crude lipid + Ash $)$.

Data are expressed as mean \pm SD from triplicate determination. 
fishes. The average crude protein content in these species was $<15.6 \mathrm{~g} / 100 \mathrm{~g}$ while the average crude lipid content was $<1.5$ $\mathrm{g} / 100 \mathrm{~g}$, which is less than the values reported for coastal water fishes.

The levels of moisture (77.3-88.1 g/100 g), crude protein (7.7-18.3 g/100 g), crude lipid (<0.1-1.4 g/100 g), ash (1.3-2.5 $\mathrm{g} / 100 \mathrm{~g})$ and carbohydrate $(<0.1-2.0 \mathrm{~g} / 100 \mathrm{~g})$ in six species of cephalopods found in the coastal waters, including cuttlefish Sepia officinalis, beka squid Octopus membranaceus, Japanese flying squid Todarodes pacificus, whiparm octopus Octopus minor, webfoot octopus Octopus ocelltus and giant Pacific octopus Enteroctopus dofleini were determined.

The water layer inhabited by squids is approximately 200 $\mathrm{m}$ from the surface. The water layer inhabited by the Japanese hooked squid Moroeuthis lonnbergi is unknown; however, these are often caught by trawl fisheries. The magistrate armhook squid was caught 500-700 m below sea level (Sohn et al., 2010). The biochemical compositions of these deep-sea animals were analyzed and shown to be similar to those of coastal sea fishes.

\section{Total and free amino acids}

The total amino acid contents of these deep-sea animals are shown in Table 3. Seventeen amino acids other than tryptophan were detected in the samples; tryptophan was damaged by hydrolysis using $\mathrm{HCl}$.

The total amino acid contents of Tanaka's eelpout, magis- trate armhook squid, and ocean sunfish endosarc, and ectosarc were 14.64, 10.75, 9.95 and $3.10 \mathrm{~g} / 100 \mathrm{~g}$, respectively. Tanaka's eelpout and ocean sunfish's endosarc contained significantly higher amounts of total amino acids than magistrate armhook squid and ocean sunfish's ectosarc. High contents of glutamic acid, aspartic acid, lysine, leucine and arginine were detected in these animals, while those of the histidine, glycine and cysteins were low. The animals were also found to be rich in glutamic acid $(2.65,1.91$, and $0.54-1.38 \mathrm{~g} / 100$ g, respectively, Tanaka's eelpout, magistrate armhook squid, and ocean sunfish). The glutamic acid contents of coastal sea fishes were analyzed and previously found to be similar to or greater than those in the present samples (1.71-1.83, 1.60-1.77 and 1.91-2.18 g/100g, respectively, in red seabream Pagrus major, brassblotched rockfish Sebastes pachycephalus pachycephalus, and olive flounder Paralichthys olivaceus) (Kim et al., 2000).

The essential amino acids ratio in Tanaka's eelpout (44\%), magistrate armhook squid (41\%), and ocean sunfish (28-46\%) was also calculated. The essential amino acids/nonessential amino acids ratios in Tanaka's eelpout, magistrate armhook squid, ocean sunfish's endosarc, and ectosarc were $0.78,0.70$, 0.84 and $0.39 \%$, respectively. The E/NE ratios of magistrate armhook squid and ocean sunfish's ectosarc were lower than the common level $(0.74 \%)$ in most of fishery products (Iwasaki and Harada, 1985; Kang et al., 2009). Sulfur, mainly in the form of sulfur-containing amino acids such as taurine, methionine and cysteine are essential for the detoxification path-

Table 3. The total amino acid content $(\mathrm{g} / 100 \mathrm{~g})$ of muscle from Tanaka's eelpout, magistrate armhook squid, and ocean sunfish

\begin{tabular}{|c|c|c|c|c|}
\hline \multirow[t]{2}{*}{ Amino acid } & \multirow{2}{*}{$\begin{array}{l}\text { Tanaka's eelpout } \\
\text { (Lycodes tanakae) }\end{array}$} & \multirow{2}{*}{$\begin{array}{l}\text { Magistrate armhook squid } \\
\text { (Berryteuthis magister) }\end{array}$} & \multicolumn{2}{|c|}{ Ocean sunfish (Mola mola) } \\
\hline & & & Endosarc & Ectosarc \\
\hline \multicolumn{5}{|c|}{ Essential amino acids (E) } \\
\hline Histidine & 0.48 & 0.35 & 0.41 & 0.18 \\
\hline Isoleucine & 0.71 & 0.45 & 0.54 & 0.06 \\
\hline Leucine & 1.21 & 0.9 & 0.9 & 0.11 \\
\hline Lysine & 1.57 & 0.95 & 0.98 & 0.16 \\
\hline Methionine & 0.58 & 0.38 & 0.41 & 0.07 \\
\hline Phenylalanine & 0.69 & 0.54 & 0.41 & 0.1 \\
\hline Threonine & 0.61 & 0.47 & 0.38 & 0.1 \\
\hline Valine & 0.58 & 0.4 & 0.5 & 0.09 \\
\hline Total E & 6.43 & 4.44 & 4.53 & 0.87 \\
\hline \multicolumn{5}{|c|}{ Nonessential amino acids (NE) } \\
\hline Arginine & 1.18 & 1.2 & 0.99 & 0.33 \\
\hline Aspartic acid & 1.47 & 1.14 & 1.05 & 0.24 \\
\hline Serine & 0.59 & 0.37 & 0.39 & 0.11 \\
\hline Glutamic acid & 2.65 & 1.91 & 1.38 & 0.54 \\
\hline Proline & 0.48 & 0.35 & 0.35 & 0.35 \\
\hline Glycine & 0.39 & 0.33 & 0.31 & 0.39 \\
\hline Alanine & 0.68 & 0.5 & 0.48 & 0.22 \\
\hline Cystine & 0.07 & 0.06 & 0.03 & 0.01 \\
\hline Tyrosine & 0.7 & 0.45 & 0.44 & 0.04 \\
\hline Total NE & 8.21 & 6.31 & 5.42 & 2.23 \\
\hline Total amino acid & 14.64 & 10.75 & 9.95 & 3.1 \\
\hline E/NE ratio & 0.78 & 0.70 & 0.84 & 0.39 \\
\hline
\end{tabular}


ways in the liver. This is one of the major roles of sulfur in the body (Kang et al., 2007). The values of sulfur-containing amino acids in Tanaka's eelpout, magistrate armhook squid, and ocean sunfish were $0.65,0.44$ and $0.08-0.44 \mathrm{~g} / 100 \mathrm{~g}$. Aromatic amino acids such as phenylalanine and tyrosine function as substance as neurotransmitters in the brain (Kang et al., 2007). The amounts of aromatic amino acids in Tanaka's eelpout $(1.39 \mathrm{~g} / 100 \mathrm{~g})$, magistrate armhook squid $(0.99 \mathrm{~g} / 100$ g) and ocean sunfish (0.14-0.85 g/100 g) were analyzed. There was very a little appreciable difference in the total amino acid composition of aquatic animals, depending on the species (Lee et al., 2000).

Free amino acids, which are a major component of active biological substances, have been shown to have distinct flavors and have been classified accordingly (Ohta, 1976). For example, glycine, alanine, threonine, proline and serine are described as sweet tasting while leucine, isoleucine, methio- nine, phenylalanine, lysine, valine and arginine are bitter tasting amino acids. Moreover, aspartic acid has a sour taste while glutamic acid is considered umami taste (Shou, 1969). The free amino acid contents of our samples are shown in Table 4. The total free amino acid values for Tanaka's eelpout, magistrate armhook squid, and ocean sunfish were 127.81, 298.43 and $16.84-39.55 \mathrm{mg} / 100 \mathrm{~g}$, respectively. The amounts of free amino acids in red seabream, brassblotched rockfish and olive flounder were previously shown to be 563.39-601.57, 451.89-530.30, and 300.18-473.75 mg/100 g, respectively, with taurine as the dominant amino acid (Kim et al., 2000). The free amino acid content in deep-sea aquatic animals was $16.84-298.43 \mathrm{mg} / 100 \mathrm{~g}$ and the taurine content was $0.61-7.21$ $\mathrm{mg} / 100 \mathrm{~g}$. These values are lower than those of coastal organisms. Taurine represented $39-65 \%$ of the free amino acid content, followed in abundance by hydroxyproline, lysine, alanine, and glycine (Kim et al., 2000). The prominent amino

Table 4. The free amino acid content ( $\mathrm{mg} / 100 \mathrm{~g}$ ) of muscle from Tanaka's eelpout, magistrate armhook squid, and ocean ocean sunfish

\begin{tabular}{|c|c|c|c|c|}
\hline \multirow{2}{*}{ Amino acid } & \multirow{2}{*}{$\begin{array}{l}\text { Tanaka's eelpout } \\
\text { (Lycodes tanakae) }\end{array}$} & \multirow{2}{*}{$\begin{array}{l}\text { Magistrate armhook squid } \\
\text { (Berryteuthis magister) }\end{array}$} & \multicolumn{2}{|c|}{ Ocean sunfish (Mola mola) } \\
\hline & & & Endosarc & Ectosarc \\
\hline Phoshoserine & 4.8 & 4.06 & 1.27 & 0.15 \\
\hline Taurine & 7.18 & 7.21 & 4.23 & 0.61 \\
\hline Phosphoethanolamine & 1.31 & 0.3 & 0.3 & nd \\
\hline Urea & 4.05 & 7.63 & 1.04 & nd \\
\hline Aspartic acid & 0.48 & nd & 0.36 & nd \\
\hline Hydroxyproline & 10.35 & 0.77 & nd & nd \\
\hline Threonine & 8.85 & 14.4 & 2.27 & nd \\
\hline Serine & 4.31 & 3.69 & 1.38 & nd \\
\hline Asparagine & nd & nd & nd & nd \\
\hline Glutamic acid & 7.27 & 27.1 & 3.18 & nd \\
\hline$\alpha$-aminoadipic acid & nd & 0.79 & nd & nd \\
\hline Proline & 7.52 & 27.74 & nd & 0.55 \\
\hline Glycine & 21.2 & 19.04 & 2.44 & 1.82 \\
\hline Alanine & 17.44 & 55.61 & 7.01 & 1.97 \\
\hline Citrulline & nd & 10.4 & nd & nd \\
\hline$\alpha$-Aminobutyric acid & 0.23 & 0.57 & nd & 0.14 \\
\hline Valine & 2.03 & 13.48 & 2.62 & 1.55 \\
\hline Cystine & nd & 2.37 & nd & nd \\
\hline Methionine & 2.89 & 14.84 & 1.18 & 0.34 \\
\hline Isoleucine & 1.31 & 11.01 & 2.38 & 1.09 \\
\hline Leucine & 2.42 & 27.06 & 3.63 & 1.99 \\
\hline Tyrosine & 1.33 & 9.7 & 2.52 & 0.5 \\
\hline Phenylalanine & 1.24 & 12.2 & 1.45 & 0.55 \\
\hline$\beta$-Alanine & 0.14 & 0.48 & nd & 0.02 \\
\hline$\beta$-Aminobutyric acid & nd & 3.92 & nd & nd \\
\hline$\gamma$-Aminoisobutyric acid & 0.37 & 1.09 & 0.24 & 0.02 \\
\hline Hisdine & 3.08 & 5.57 & 0.57 & 0.3 \\
\hline Methyhisdine & 0.07 & nd & nd & 0.06 \\
\hline Carosine & nd & nd & nd & nd \\
\hline Tryptophan & nd & 17.4 & 0.63 & 0.92 \\
\hline Ornithine & 0.53 & nd & 0.09 & 0.36 \\
\hline Lysine & 4.2 & nd & nd & 1.32 \\
\hline Ammonia & 0.26 & nd & 0.16 & 0.09 \\
\hline Arginine & 12.95 & nd & 0.6 & 2.49 \\
\hline Total & 127.81 & 298.43 & 39.55 & 16.84 \\
\hline
\end{tabular}

nd, not detected. 
acids in Tanaka's eelpout were glycine, alanine, and arginine.

Magistrate armhook squid had high contents of proline, glycine, alanine and leucine whereas ocean sunfish contained only minor amounts of free amino acids. In general, the alanine and glycine contents were highest in deep-sea aquatic animals and coastal organisms; however, there was no significant similarity between them.

\section{Fatty acid composition}

The total fatty acid compositions of the deep-sea animals are shown in Table 5. The prominent saturated fatty acids (SFAs) were C16:0 in Tanaka's eelpout and magistrate armhook squid and C18:0 in ocean sunfish. The content of monounsaturated fatty acids such as palmitoleic acid (C16:1) and oleic acid (18:1) were not different in these samples except for Tanaka's eelpout.

The prominent fatty acids in coastal fishes are C16:0,
C20:0, C22:6, C18:1, C20:5, and C16:1 (Kang et al., 2007). Similar to coastal fishes, the major fatty acids in deep-sea aquatic animals were C16:0, C18:0, C16:1, C18:1, C20:5, and $\mathrm{C} 22: 6$. In contrast, Tanaka's eelpout had a high $\mathrm{C} 18: 1$ content while C22:6 was the most abundant fatty acid in magistrate armhook squid and ocean sunfish.

The fatty acid contents in five species of migratory fish (Japanese anchovy E.joponicus, flathead grey mullet M. cephalus, dotted gizzard shad K. punctatus, Japanese amberjack Seriola quinqueradiata, and common mackerel Scomber japonicas), three species of coastal and reef-dwelling fish (black rockfish Sebastes schlegelii, red seabream P. major, and blackhead seabream Acanthopagrus schlegelii schlegelii), and four species of demersal fish (ridged-eye flounder Pleuronichthys cornutus, whitespotted conger Conger myriaster, olive flounder P. olivaceus, and black scraper Thamnaconus modestus) were analyzed previously and shown to comprise large proportions of unsaturated fatty acids (Jeong et al., 1999). The total fatty

Table 5. The fatty acid composition (area\%) of muscle from Tanaka's eelpout, magistrate armhook squid, and ocean sunfish

\begin{tabular}{|c|c|c|c|c|}
\hline \multirow[t]{2}{*}{ Fatty acid } & \multirow{2}{*}{$\begin{array}{l}\text { Tanaka's eelpout } \\
\text { (Lycodes tanakae) }\end{array}$} & \multirow{2}{*}{$\begin{array}{l}\text { Magistrate armhook squid } \\
\text { (Berryteuthis magister) }\end{array}$} & \multicolumn{2}{|c|}{ Ocean sunfish (Mola mola) } \\
\hline & & & Endosarc & Ectosarc \\
\hline C14:0 & 1.69 & 1.91 & 0.61 & 0.21 \\
\hline C15:0 & 0.21 & 0.23 & 0.21 & 0.66 \\
\hline $\mathrm{C} 16: 0$ & 12.88 & 18.89 & 15.79 & 20.16 \\
\hline $\mathrm{C} 17: 0$ & 0.22 & nd & 0.38 & 0.61 \\
\hline $\mathrm{C} 18: 0$ & 2.08 & 2.05 & 15.81 & 12.31 \\
\hline $\mathrm{C} 20: 0$ & 0.06 & 0.3 & 1.11 & 0.64 \\
\hline $\mathrm{C} 22: 0$ & nd & nd & nd & 5.9 \\
\hline $\mathrm{C} 14: 1$ & 0.12 & nd & nd & 0.15 \\
\hline $\mathrm{C} 15: 1$ & nd & nd & nd & 1.12 \\
\hline $\mathrm{C} 16: 1$ & 8.94 & 1.69 & 2.04 & 0.95 \\
\hline $\mathrm{C} 17: 1$ & 0.31 & nd & 0.3 & 1.12 \\
\hline $\mathrm{C} 18: 1$ & 32.77 & 8.55 & 16.8 & 14.33 \\
\hline $\mathrm{C} 20: 1$ & 3.45 & 5.2 & 1.76 & 5.45 \\
\hline $\mathrm{C} 22: 1$ & 1.29 & 3.75 & 0.54 & nd \\
\hline $\mathrm{C} 16: 2$ & nd & nd & 1.11 & 0.81 \\
\hline $\mathrm{C} 18: 2$ & 1.31 & 0.72 & 1.26 & 0.6 \\
\hline $\mathrm{C} 18: 3$ & 0.62 & 0.25 & 0.6 & 1.06 \\
\hline $\mathrm{C} 18: 4$ & 0.89 & 0.46 & 0.77 & 0.24 \\
\hline $\mathrm{C} 20: 2$ & 0.23 & 1.6 & 0.36 & 0.4 \\
\hline $\mathrm{C} 20: 3$ & 2.29 & 1.15 & 7.96 & 0.13 \\
\hline C20:4 & 0.3 & 0.9 & 0.23 & 7.92 \\
\hline C20:5n-3 EPA & 11.91 & 14.48 & 9.81 & 7.14 \\
\hline $\mathrm{C} 22: 4$ & nd & nd & 0.79 & 0.51 \\
\hline C22:5n-3 DPA & 0.55 & 1.06 & 3.24 & 3.31 \\
\hline C22:6n-3 DHA & 17.89 & 36.46 & 18.52 & 13.29 \\
\hline$\sum$ Saturates & 17.14 & 23.38 & 33.91 & 40.49 \\
\hline$\sum$ Monoenes & 46.88 & 19.19 & 21.44 & 23.12 \\
\hline$\sum$ Polyenes & 35.99 & 57.08 & 44.65 & 35.41 \\
\hline UFA/SFA & 4.83 & 3.26 & 1.95 & 1.42 \\
\hline MUFA/SFA & 2.74 & 0.82 & 0.63 & 0.57 \\
\hline PUFA/SFA & 2.10 & 2.44 & 1.32 & 0.86 \\
\hline
\end{tabular}

nd, not detected.

Unsaturated fatty acids/saturated fatty acids.

Monounsaturated fatty acids/saturated fatty acids.

Polyunsaturated fatty acids/saturated fatty acids. 
acid compositions of the samples in this study, with the exception of Tanaka's eelpout, were analyzed and found to comprise large proportions of SFAs, such as C16:0, and C18:0. However, magistrate armhook squid had high levels of polyunsaturated fatty acids, such as EPA (20:5n-3) and DHA (C22:6n-3). Thus, ingestion of magistrate armhook squid may have health promoting effects.

The major unsaturated fatty acids in twelve species of coastal fishes were previously shown to be DHA, EPA, C20:4n-6, and DPA (C22:5n-3) (Jeong et al., 1998b). The DHA content (7.26-28.4\%) was highest in black scraper and lowest in flathed grey mullet. The EPA content (4.21-17.9\%) was highest in ridge-eye flounder and lowest in Japanese amberjack (Jeong et al., 1999).

Flathead grey mullet, dotted gizzard shad, and ridge-eye flounder had high levels EPA while the other species had abundant DHA. Black scraper possessed $>5 \%$ C20:4n-6, while flathead grey mullet, blackhead seabream, and ridgeeye flounder possessed $<5 \%$ DPA (Jeong et al., 1999). All of the deep-sea animal samples had circa twice as much DHA as EPA. Moreover, these samples contained trace DPA. The total fatty acid compositions of the deep-sea animals were similar to those of coastal organisms.

\section{Acknowledgments}

This research was supported by a grant from the National Fisheries Research and Development Institute (RP-2012FS-003).

\section{Reference}

Ackman RG. 1989. Nutritional composition of fats in seafoods. Prog Food Nutr Sci 13, 161-241.

American Oil Chemists' Society. 1997. Official Methods Ce 1b-89. Official methods and recommended practices of the AOCS. 5th ed. AOCS, Champaign, IL, US

Association of Official Analytical Chemists. 1990. Official Methods of Analysis. 15th ed. Association of Official Analytical Chemists. Arlington, VA, US.

Barnes RSK and Mann KH. 1991. Fundamentals of Aquatic Ecology. Blackwell Publishing Ltd., Oxford, GB.

Folch J, Lees M and Sloane Stanley GH. 1957. A simple method for the isolation and purification of total lipides from animal tissues. J Biol Chem 226, 497-509

Hernandez MD, Egea MA, Rueda FM, Martinez FJ and Garcia BG. 2003. Seasonal condition and body composition changes in sharpsnout seabream (Diplodus puntazzo) raised in captivity. Aquaculture 220, 569-580.
Iwasaki M and Harada R.1985. Proximate and amino acid composition of the roe and muscle of selected marine species. J Food Sci 50, 1585-1587.

Jeong BY, Choi BD and Lee JS. 1998a. Proximate composition, cholesterol and a-tocopherol content in 72 species of Korean fish. J Korean Fish Soc 31, 160-167.

Jeong BY, Choi BD, Moon SK and Lee JS. 1998b. Fatty acid composition of 72 species of Korean fish. J Fish Sci Technol 1, 129-146.

Jeong BY, Moon SK, Choi BD and Lee JS. 1999. Seasonal variation in lipid class and fatty acid composition of 12 species of Korean fish. J Korean Fish Soc 32, 30-36.

Kang HW, Shim KB, Kang DY, Jo KC, Song KC, Lee JH, Song HI, Son SG and Cho YJ. 2007. Sitological quality evaluation of cultured and wild river puffer Takifugu obscurus (Abe). J Aquac 20, 147-153.

Kang HW, Shim KB, Cho YJ, Kang DY, Cho KC, Kim JH and Park KJ. 2010. Biochemical composition of the wild and cultured yellow croaker (Larimichthys polyactis) in Korea. Korean J Fish Aquat Sci 43, 18-24.

Kim HY, Shin JW, Park HO, Choi SH, Jang YM and Lee SO. 2000. Comparison of taste compounds of Red Sea Bream, Rockfish and Flounders differing in the localities and growing conditions. Korean J Food Sci Technol 32, 550-563.

Kim JN, Choi JH, Hong BG, Hwang KS and Chun YY. 2007. Two hippolytid shrimps (Crustacea: Decapoda: Caridea) from the deepwater of the East Sea, Korea. Korean J Syst Zool 23, 199-203.

Lee BY and Surh J. 2011. Seasonal variations in the nutritional compositions and heavy metals in two demersal fish, Liparis tessellatus (cubed snailfish) and Hemitripterus villosus (shaggy sea raven). Korean J Food Sci Technol 43, 282-290.

Lee HY, Park MW and Jeon IG. 2000. Comparison of nutritional characteristics between wild and cultured juvenile black rockfish, Sebastes schlegeli. J Korean Fish Soc 33, 137-142.

Mok JS, Lee DS, Yoon HD, Park HY, Kim YK and Wi CH. 2007. Proximate composition and nutritional evaluation of fisheries products from the Korean coast. J Korean Fish Soc 40, 259-268.

Ohta S. 1976. Food Seasoning. Saiwaisyobow, Tokyo, JP.

Park HH and Bae BS, 2011. Catch species composition with some different traps by depth in the deep-water of the East Sea. J Korean Soc Fish Technol 47, 300-315.

Park HH, Jeong EC, Bae BS, Yang YS, Hwang SJ, Park JH, Kim YS, Lee SI and Choi SH. 2007. Fishing investigation and species composition of the catches caught by a bottom trawl in the deep East Sea. J Korean Soc Fish Technol 43, 183-191.

Shindo K, Tsuchiya T and Matsumoto JJ. 1986. Histological study on white and dark muscles of various fishes. Nippon Suisan Gakkaishi $52,1377-1399$.

Shou H. 1969. Food component and taste. J Food Ind Jpn 16, 83-87.

Sohn MH, Lee H, Hong BK and Chun YY. 2010. Seasonal variation of species composition by depths in deep sea ecosystem of the East Sea of Korea. J Korean Soc Fish Technol 46, 376-391. 